\title{
Same process, different meaning: / $\varepsilon /$ lowering over time in Louisiana Regional French
}

\author{
DARCIE BLAINEY
}

University of Toronto

(Received April 20I4; revised May 2015)

\section{A B S T R A C T}

This paper examines / $\varepsilon /$ lowering before / $\mathrm{r} /$ in Louisiana Regional French (e.g., père, /per/ $\rightarrow$ [pær], [per] 'father') between I977 and 20 I I in a small geographic region. The analysis of 436 tokens from 32 speakers shows that $/ \varepsilon /$ lowering has changed through time from a generational to a geographical boundary marker. This explains differing $/ \varepsilon /$ lowering rates reported in the literature (Guilbeau, I950; Dubois, 2005; Salmon, 2009). Results confirm that sociolinguistic factors play an active role in Louisiana Regional French, despite its endangered status (Dajko, 2009; Dubois, 2005), underscoring the need to better control for diatopic factors in future research.

\section{INTRODUCTION}

This paper examines a particular vowel pattern in Louisiana Regional French, / $/$ / lowering to $[æ]$ before $/ \mathrm{r} /$, tracking its use over the last four decades. An example of this process is the word père /per/ 'father', which can either be pronounced with the non-lowered variant [per] or with the lowered variant [pær]. The study uses data from recordings made in I977 and 20IO-20II in a small geographic region, altogether examining 436 tokens from 32 speakers born between I 888 and I953. It is only by considering sociolinguistic factors not included in existing analyses (birth year and home town) that previously unreported patterns emerge from the data.

Dialectal variation in Louisiana Regional French forms the core of numerous linguistic studies, whether they be in the domain of syntax or phonology. Some studies have also focused on $/ \varepsilon /$ lowering before $/ \mathrm{r} /$. These studies have compared speech from different Louisiana parishes (the Louisiana equivalent of counties) to see if the use of this variable changes based on a person's home parish (Dubois, 2005; Salmon, 2009), or have reported on a single parish (Guilbeau I950, I958). This study focuses on one area in particular, lower Lafourche Parish, examining variation at the municipal, rather than the parish, level. The motivation for this narrow geographical scope comes as a result of recordings made in lower Lafourche Parish. There, some (but not all) speakers appear to lower $/ \varepsilon /$ before $/ \mathrm{r} /$ much more frequently than is predicted in the literature. 


\section{Darcie Blainey}

\subsection{Language variety}

Louisiana Regional French (more commonly known as Cajun French) is an orallytransmitted language, and so the vast majority of native speakers do not read or write in French. It is also a severely endangered language according to the UNESCO nine-factor Language Vitality and Endangerment (LVE) scale (Brenzinger et al., 2003), which means that it is no longer being passed on to children, is spoken by a minority of the population in a limited number of settings, and is not necessarily available through education or popular media. Indeed, while the Council for the Development of French in Louisiana (CODOFIL), created in I968, has worked to promote French language use in Louisiana, the objective has been to teach and use outside varieties of French with higher perceived social status, such as Canadian, Belgian and France French; more recently, the aim has turned to using ('Standard') French to attract Francophone tourists to the state.

The present study examines Louisiana Regional French speakers, but it is important to note that this language variety is one of at least three that exist in Louisiana. For instance, Louisiana Plantation Society ('Colonial') French (Picone, I998) is more closely related to 'Standard' French (SF) and has practically disappeared as its affluent speakers shifted to English (Brasseaux, I992). Also, Louisiana Creole French is linguistically similar to Haitian Creole and Antillean Creole, but developed independently among the African slaves brought to Louisiana in the I700s (Neumann, I985). Unfortunately, Louisiana Creole French has not enjoyed the positive status, publicity, and revitalization efforts consecrated to Louisiana Regional French, which is likely due to long-standing ethnic disparities and prejudices in the state (Trépanier, I991: I64). As a result, Louisiana Creole French is more severely endangered than Louisiana Regional French. All three varieties have been in heavy contact with English for over a century; this language contact, along with its effects on Louisiana Regional French, is well documented in the academic literature (Picone and Valdman, 2005; Brasseaux, 2005).

Louisiana Regional French shares some interesting similarities with Jersey Norman French, another endangered variety spoken on one of the Channel Islands between England and France. Known as Jèrriais to native speakers, roughly 3 percent of the island's population still speaks it in private settings, and the majority of speakers are over 60 years of age (Jones, 2005: 4). As with Louisiana Regional French, there is widespread dialect variation (Jones, 200 I: 38 ), little to no contact with SF (Jones, 2012: 20I), and no official federal backing for the language variety (Jones, 200I: 73).

There are also important differences between Louisiana Regional French and Jersey Norman French. For instance, English has only come into regular and heavy contact with French in Louisiana over the last I 50 years, but it has been a part of daily life since the fifteenth century on Jersey (Jones, 2005: 4). Also, while Louisiana French speakers cannot read in French, most speakers of Jèrriais can (Jones, 200 I: 52). Finally, language revitalization efforts in Louisiana are complicated by disagreements regarding which variety of Louisiana Regional French to implement as the norm (Brown, 2005: 399). However, on Jersey, speakers can agree 
on one standard variety (Jones, 200I: 87), and the majority of Jèrriais speakers want the language preserved (Jones, 200I: 62) and in schools (Jones, 200I: 64).

\subsection{Region}

Lafourche Parish sits at the southwestern edge of the state of Louisiana, running North to South from below the Mississippi river to the Gulf Coast. Three main transportation thoroughfares run down the parish: Highways I and 308 for vehicles, and bayou Lafourche for watercraft (a bayou is a slow-moving waterway in the Louisiana landscape). The land itself lies between o and I metres above sea level, and is increasingly marshland as one travels south. Below the town of Golden Meadow, for instance, the road becomes a ribbon of land completely surrounded by marsh. As a result, traditional ways of life, especially in the southern half of the parish, focused on shrimping and fishing in the summer, and trapping in the winter.

The smaller communities in the southern part of the parish, such as Cut Off, Galliano, and Golden Meadow, exhibit a history of endogamy (as evidenced by the prevalence of certain family names), strong religious ties to Catholicism, and prevalent French use. For instance, the churches of Cut Off and Golden Meadow were the last two French-language Catholic institutions in the state before they switched to English record-keeping in the I950s (Dubois, Leumas, and Richardson, 2007: 60; Leumas, 2009: 83). Also, before the oil boom in the I940s, the lower half of the parish was fairly isolated from English-speaking outsiders (Larouche, I979).

An isogloss boundary exists between Larose and Cut Off, separating the upper half of the parish from the lower half (Dajko et al., 2008). This reflects settlement patterns of different French-speaking groups. Acadian settlers stayed mostly in the northern and central parts of bayou Lafourche, making their way as farmers (Brasseaux, I985; Smith, I934) and trickling down the bayou in smaller numbers. In contrast, many residents of lower Lafourche Parish, particularly those from Golden Meadow, can trace their ancestry to the fishing village of Chenière Caminada at the southeastern tip of the parish, whose Francophone population hailed mainly from France, not Acadia (Pitre, I996: 58). Accordingly, lower Lafourche Parish French does not exhibit typically Acadian linguistic traits (Baronian, 2005; Byers, I988; Rottet, 2004), with the exceptions of lexically conditioned affrication (e.g., queue [tøø] 'tail', diable [dzab] 'devil') and stylistic variation between [3] and [h] (e.g., je $/ 30 / \rightarrow$ [3ə], [ho] 'I').

Figure I gives the geographical situation of Lafourche Parish within Louisiana, while Figure 2 provides a parish-specific map of the towns of Lafourche. Chenière Caminada is located to the northeast of Port Fourchon on Highway I.

\section{$1.3 / \varepsilon /$ lowering in North American French}

$/ \varepsilon /$ lowering before a rhotic consonant occurs in many varieties of North American French; in several varieties of Canadian French, the lowered vowel can appear when the rhotic precedes another consonant. Walker (I984: 86) notes that this 


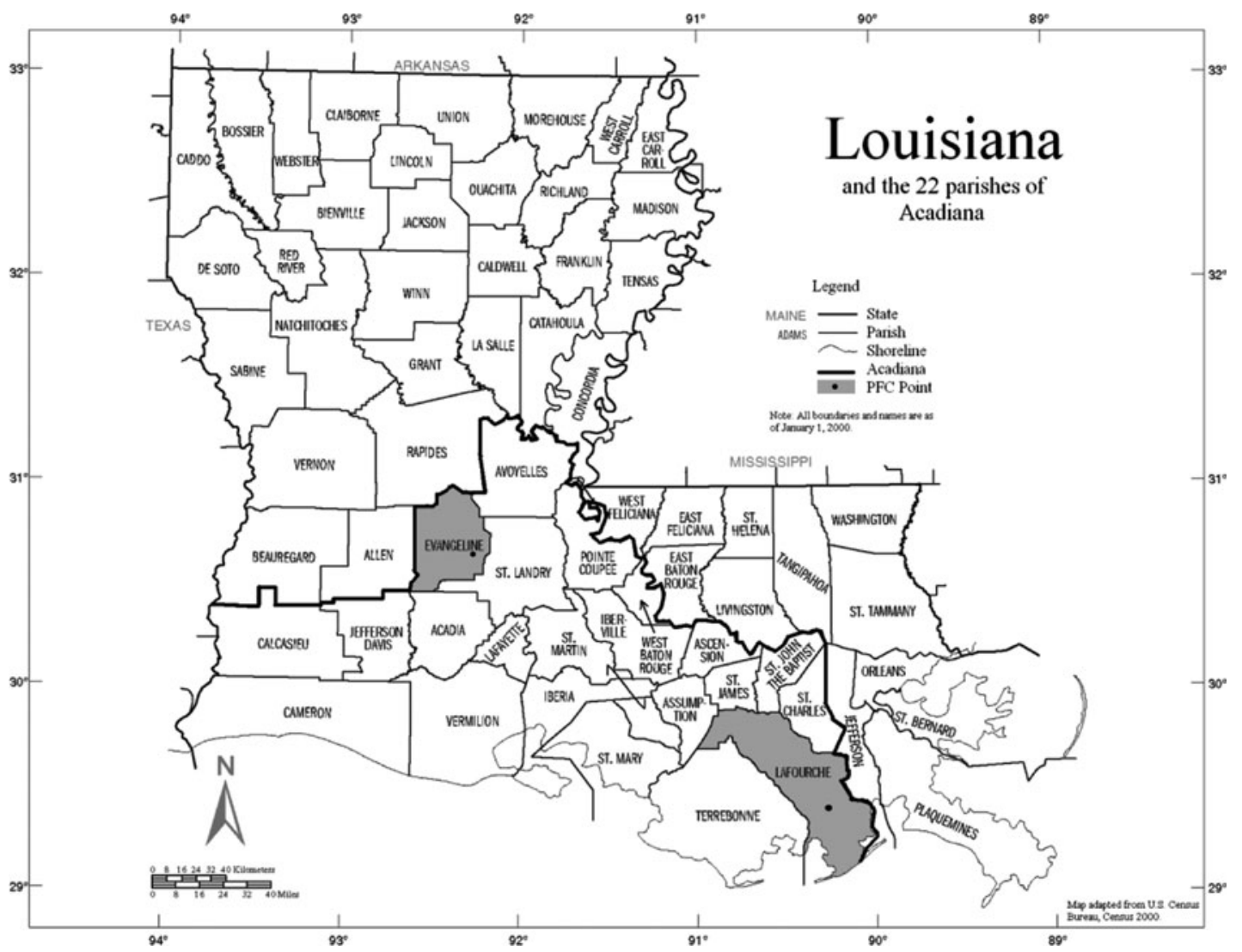

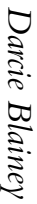

Figure I. The 64 parishes of Louisiana, including the 22 southern parishes of the French Triangle of Acadiana. Note. From U.S. Census Bureau, Census 2000. Adapted with permission, originally in Blainey (2013). 


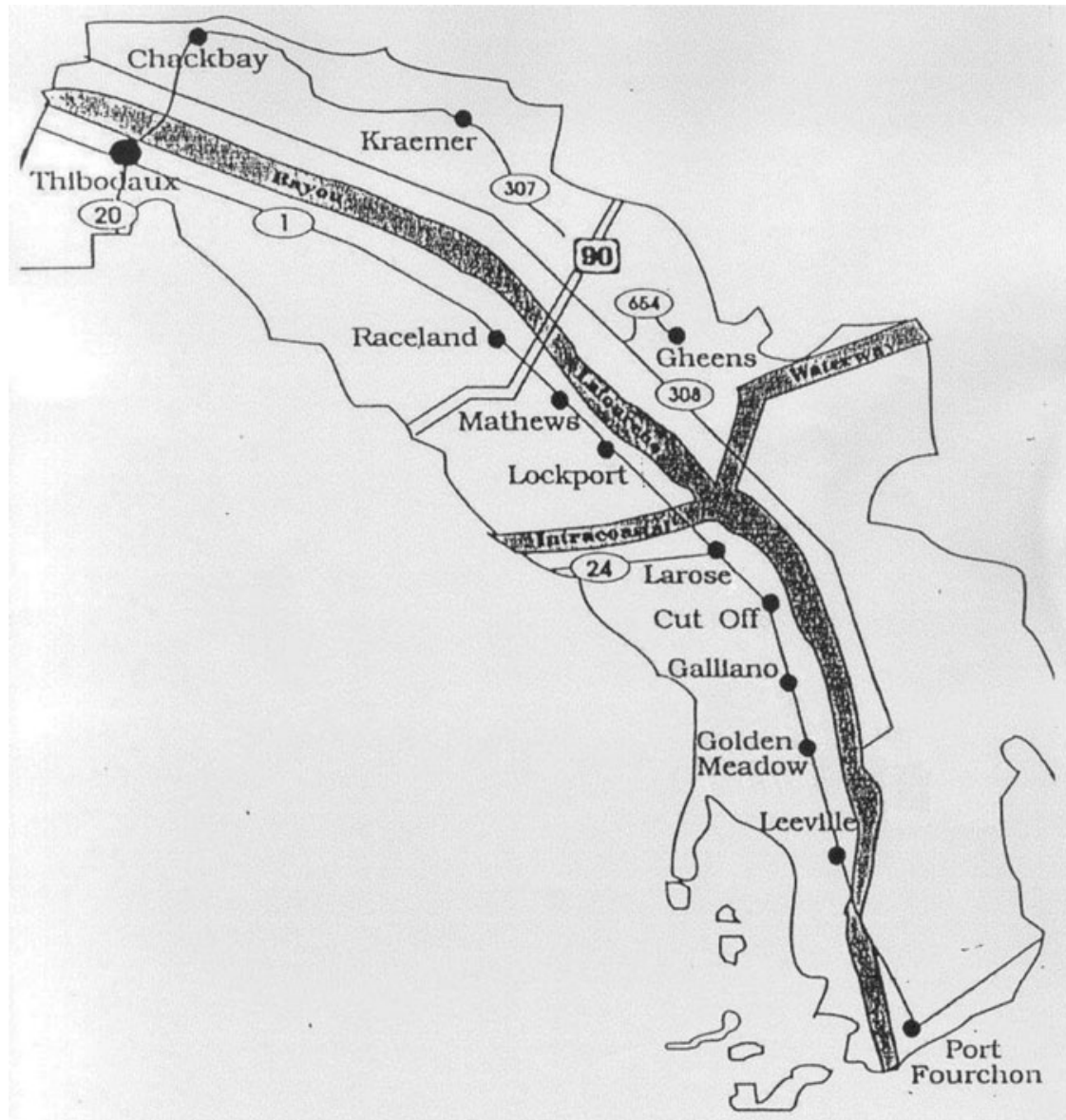

Figure 2. Lafourche Parish outline with towns, major roads and waterways. Note. From the Lafourche Parish Government website, retrieved December I5, 20I2, http://www.lafourchegov.org/parishimages/ParishBlackWhite.jpg. Reprinted with permission.

pronunciation pattern is most common in Montreal and the Outaouais area, and 'is often considered rural, archaic or otherwise stylistically marked', giving examples like aubarge [SF auberge] (/ober3/ $\rightarrow$ [o.bar3] 'hostel'). The same lowering is attested in the Acadian French of the Îles-de-la-Madeleine (Falkert, 20го: I76-I77) and New Brunswick (Flikeid, I984: I82-I85); in Ontario French (Hull, I956); and in Manitoba French (Thogmartin, 1974).

In his sociolinguistic study of the history of Parisian French, R. Anthony Lodge explains that [er] lowering to [ar] was a feature of vernacular Parisian French 


\section{Darcie Blainey}

in the thirteenth century (Lodge, 2004: 94), and it also appears in the personal correspondence of sixteenth-century aristocrats and royalty (Lodge, 2004: I45). Salmon (2009: 64) notes that French grammarians have recorded variable $e$ before $r$ since the sixteenth century, and that this variation is likely due to the fact that the French vowel actually stems from two different Latin vowels, /a/ and / $/ \varepsilon$. Although the French Revolution of I 789 was 'politically progressive', Lodge (2004: 207) observes that it was 'linguistically conservative', so that [ar] endured as a stigmatized pronunciation variant in lower-class Parisian French at least until I 82 I. However, Dubois (2005: 294) remarks that the lowered variant became popular in France at the turn of the eighteenth century, a time when many French citizens immigrated to Louisiana. Since the ancestors of Golden Meadow speakers arrived mainly from France, it is reasonable to assume that they were conscious of the longstanding, stigmatized nature of $/ \varepsilon /$ lowering before $/ \mathrm{r} /$, but also that this process was present in their everyday speech.

In Louisiana Regional French, many words undergo the process whereby $/ \varepsilon$ / lowers to [æ] before $/ \mathrm{r} /$, regardless of syllable structure $(/ \mathrm{r} /$ can occupy a coda or an onset position). So, a word like frère (/frer/ 'brother') can be pronounced [frer] or [frær] regardless of whether the word-final consonant is resyllabified with a following vowel-initial word.

The phenomenon of $/ \varepsilon /$ lowering before / $\mathrm{r} /$ figures in early descriptions of Louisiana Regional French, with Alcée Fortier (I891: 88) noting its presence in both St. Martin and St. Mary Parish. Citing Fortier (I89I), William Read (I93 I: $\mathrm{xx}$ ) states that 'the tense vowel in St.-Fr. faire, etc., becomes lax' in Louisiana Regional French, without specifying geographic boundaries for the phenomenon. The same author, in his mini-dictionary of Louisiana French, lists a single word with a lowered / $/$ /, gouère ([gwæ:r], 'blond-haired, blue-eyed person'), stating that the word is used in the parishes of Lafayette, Iberia, Avoyelles, St. Landry and St. Martin (Read, I938: 74). Other words in the dictionary either do not have an accompanying phonetic transcription, as in sarbotière [SF sorbétière] ('ice-cream freezer') (Read, I938: 82), or use the non-lowered variant, as in gaspergou [SF casseburgot] ('fresh-water drum') (Read, I938: 72). Finally, in their Louisiana French grammar of Lafayette, St. Landry, and St. Martin Parishes, Marilyn Conwell and Alphonse Juilland (I963: 44) assert that $[\varepsilon]$ is in free variation with [a] before $/ \mathrm{r} /$. The authors cite the works of Trappey (I940), Hurst (I936) and Montgomery (I94I) to note that this also occurs in Iberia, St. Charles, and Vermilion Parishes, respectively.

\section{$1.4 / \varepsilon /$ lowering in Lafourche Parish}

Four previous studies of Louisiana Regional French examine Lafourche Parish speakers and $/ \varepsilon /$ lowering before $/ \mathrm{r} /$, and make different assertions about how often the process takes place. First, Guilbeau (I950: 44-45) gives an early picture of Lafourche Parish Louisiana Regional French, stating that all transcribed Lafourche speakers in his analysis, born between I 858 and I9I7 and recorded in the I940s, 
lower $/ \varepsilon /$ before / $\mathrm{r} /$ word-internally at least some of the time. Demographic information is available for Guilbeau's speakers, but he does not provide specific $/ \varepsilon /$ lowering frequencies for any of them in his description. However, in a more general description of Lafourche Parish French phonology, Guilbeau (I958: 30) does note that syllable-internal $/ \varepsilon /$ before $/ \mathrm{r} /$ most often surfaces as [æ], with only exceptional cases of $[\varepsilon]$ or $[\mathrm{e}]$.

Dubois (2005) analyzes a corpus of I20 speakers recorded in I997, as well as I7 speakers recorded in I975. The speakers' birth years range between I 890 and 1977. Thirty of the speakers come from various towns in Lafourche Parish, but quantitative comparisons occur at the parish, rather than at the municipal, level. In contrast to Guilbeau (I958), Dubois (2005: 298) concludes that Lafourche Parish speakers' pattern of use, with only $26 \%$ of all attestations using the lowered variant, does not clearly distinguish them from speakers belonging to Vermilion, St. Landry, and Avoyelles parishes. However, without differentiating between speakers' towns of origin, the analysis does not explore the possibility of dialectal variation the municipal level, presenting Lafourche Parish as homogenous with respect to $/ \varepsilon$ / lowering rates.

Finally, Salmon $(2007,2009)$ uses a subset of the recordings from Dubois (2005), examining the speech of 29 female speakers born between I 892 and I947. Six of the women come from Lafourche Parish, hailing from the towns of Galliano (I), Cut Off (4), and Raceland (I) (Salmon, personal communication, January I9, 20I3), and their birth years range from I9IO to I938; all six were recorded in I997. The small sample size does not allow for any sociolinguistic conclusions to be drawn regarding the influence of age or birthplace on allophone use in Lafourche Parish, but Salmon does note, based on two speakers, that younger speakers in Lafourche Parish rarely use the lowered variant, $a$ (Salmon, 2009: 88). Her results are therefore in keeping with Dubois (2005).

Thus, while these studies recognize that this variable may be controlled by sociolinguistic factors, quantitative measures are scarce and require further precision. All three researchers use speakers from throughout Lafourche Parish to make generalizations about $/ \varepsilon /$ lowering patterns, without considering the possibility that certain locales may differ in their deployment of this process. The current study will examine the speech of informants from Golden Meadow and the immediately surrounding area in lower Lafourche Parish, using recordings from I977 and 201020II. As the present work controls the factors of locale and ethnic identity while contrasting sex, time period, birth year and speech style among 32 speakers, it is in a position to show which of these factors play a decisive role in pronunciation patterns.

\section{HYPOTHESES}

Results from the existing academic literature on $/ \varepsilon /$ lowering before /r/ lead to three hypotheses about the process in Lafourche Parish Louisiana Regional French. The first is that $/ \varepsilon /$ will not lower to [æ] frequently for speakers interviewed in the 


\section{Darcie Blainey}

I970s or 2000s, given the results in Dubois (2005) and Salmon (2007, 2009), but it will generally lower to [æ] for speakers interviewed in the I940s (Guilbeau, I958). The second hypothesis is therefore that the point in time at which an interview takes place will play a role in a speaker's rate of $/ \varepsilon /$ lowering. The third hypothesis comes from sociolinguistic research on Lafourche Parish Francophones (e.g., Carmichael, 2007, 2008; Dajko, 2009; Larouche, I979, I980; Rottet, I995): sociolinguistic factors such as sex, age, and speech register will influence pronunciation patterns in Lafourche Parish Louisiana Regional French.

\section{METHOD}

\subsection{Speakers}

This analysis draws on two sets of recordings. The first set of interviews took place in 1977, when Alain Larouche spoke with residents of Golden Meadow and the surrounding area for his master's research (Larouche, I979, I980). His purpose was to uncover the social fabric of Golden Meadow, and so the interviews focus on local pastimes, family trees and the history of the area. Since the interviews were not conducted as part of a linguistic study, there was less of a focus on sound quality, speakers' language use or language tasks, and only one speech register is available for each speaker. The interviews were part of a Canadian multi-university documentation effort, the Louisiana Project (Projet Louisiane, Breton and Louder, I979; Louder and Waddell, I979). First made on cassette tape, the sound files have since been digitized at the University of Louisiana at Lafayette's Center for Cultural and Eco-Tourism (CCeT) (http://ccet.louisiana. edu/tourism/cultural/archives.html). Twelve interview files (seven men, five women) have been selected from the collection because they are sufficiently clear for phonetic and phonological analysis.

Another set of digital recordings were made in 2010 and 20I I, when Darcie Blainey interviewed residents of the Golden Meadow area for her doctoral research (Blainey, 2013). The objective was to restrict the geographical area as much as possible in order to control for any pronunciation variation stemming from diatopic factors. Twenty interviews, evenly divided by the interviewee's sex, have been selected for analysis. Twelve of the recordings form part of the Phonology of Contemporary French project (la Phonologie du Français Contemporain [PFC], Durand, Laks and Lyche, 2002, 2005), an international linguistic initiative to document and understand French as it is spoken worldwide.

Since the vast majority of Louisiana Regional French speakers do not read or write in their native tongue, the PFC-Louisiana protocol eliminates any textbased tasks in favor of conversational tasks: guided (formal) conversation, free (informal) conversation, sentence translation, and word translation (Klingler and Lafleur, 2007). Interviewees carry on the formal conversation with a community outsider and the informal conversation with a community insider in order to maximize the difference between conversational speech registers (Labov, I984). The 
current analysis examines data from the conversational portions of the interviews in order to compare them with conversational data in the Larouche corpus. Also, the code name for each speaker consists of two letters followed by a number as the speaker identifier, followed by the speaker's birth year and sex. For example, DCI-I $888-M$ is a male speaker born in I 888 .

Eleven of the I 2 interviewees recorded in I977 were born between I 888 and I939 in the area surrounding Golden Meadow, and all $\mathrm{I} 2$ were living in either Chenière Caminada, Golden Meadow or Galliano when they were interviewed. JBI-I923$M$ represents the only exception among the I977 speakers, because he was born in the state of Arkansas. However, he learned French upon moving to Golden Meadow, married local native speaker MBI-I924-F, and does not display nonnative characteristics in his Louisiana Regional French. JBI-I923-M is therefore included in the analysis.

As for the 20I0-20 I interviewees, they were all born and living in either Golden Meadow, Galliano or (more rarely) Cut Off, and their birth years range between I92 I and I953. All but one (GGI-I953-M) were retired when they volunteered to be interviewed, and their level of education varies between university degrees (GGI-I953-M, JAI-I926-M) and no schooling (CGI-I928-M, GG2-I929-F).

\subsection{Speech tokens}

The study uses five minutes of phonemically transcribed speech for each speaker and speech style, resulting in 260 minutes of speech overall (I 2 speakers x I speech style x 5 minutes; 20 speakers $\times 2$ speech styles x 5 minutes). This database of over 70,000 sounds yields 436 tokens of potential $/ \varepsilon /$ lowering for analysis.

The two possible surface forms for $/ \varepsilon /$ before $/ \mathrm{r} /$ in the corpus are $[\varepsilon]$ and $[æ]$. The following steps were taken to determine the correct surface form for each speech token. First, the author listened to each potential site of $/ \varepsilon /$ lowering and identified the surface variant based on perceptual cues. Second, any cases of uncertainty were verified with a native speaker of lower Lafourche Parish.

\section{RESULTS}

\subsection{7 interviews}

In the I977 corpus, there are 77 tokens for analysis. It should be noted that some speakers contribute only a few tokens to the data set; nevertheless, a consistent pattern still emerges. Specifically, there is a sharp, age-based divide in the rate of $/ \varepsilon /$ lowering: speakers born between I 888 and I920 lower $/ \varepsilon /$ between $0 \%$ and $27 \%$ of the time, and speakers born after 1920 lower $/ \varepsilon /$ between $50 \%$ and $100 \%$ of the time. Table I summarizes this information.

Indeed, there is a statistically significant positive correlation between a speaker's birth year and his or her rate of $/ \varepsilon /$ lowering to [æ] before $/ \mathrm{r} /, r_{s}=.66, \mathrm{~N}=$ I2, $p=.02$. This means that as a speaker's age decreases, the rate of [æ] before 


\section{Darcie Blainey}

Table I. / $/ \varepsilon /$ Lowering to [a] before / $r /$ for 1977 Speakers. $*=$ Birth year within 2010-2011 speakers' birth year range. $C C=$ Chenière Caminada; $C F=$ Cut Off; $E L=$ Elliot, Arkansas; $G L=$ Galliano; $G M=$ Golden Meadow; $L V=$ Leeville.

\begin{tabular}{|c|c|c|c|c|}
\hline Speaker-Birth Year-Sex & Born In & Living In & $\mathrm{N}[\mathrm{ae}] / / \mathrm{r} /$ & $\%[\mathrm{ae}] /{ }_{-} / \mathrm{r} /$ \\
\hline DCI-I $888-\mathrm{M}$ & $\mathrm{CC}$ & $\mathrm{CC}$ & 4 of 15 & $26.7 \%$ \\
\hline ES2-I9O4-M & GM & GM & I of 9 & II.I\% \\
\hline WLI-I907-M & LV & GM & $\mathrm{O}$ of 2 & $0.0 \%$ \\
\hline LCI-I9I8-M & GM & GM & I of 7 & $\mathrm{I} 4.3 \%$ \\
\hline EGI-I920-F & GM & GM & o of 2 & $0.0 \%$ \\
\hline JBI-I923-M* & EL & GM & 7 of IO & $70.0 \%$ \\
\hline MBI-I924-F* & GM & GM & 3 of 3 & $100.0 \%$ \\
\hline AGI-I928-M* & CF & GL & 4 of 4 & $100.0 \%$ \\
\hline AAI-I929-F* & GM & GM & 5 of 5 & $100.0 \%$ \\
\hline DGI-I928-F* & GM & GM & 7 of 7 & $100.0 \%$ \\
\hline ETI-I93I-F* & GL & GL & 3 of 6 & $50.0 \%$ \\
\hline CSI-I939-M* & GM & GM & 6 of 7 & $85.7 \%$ \\
\hline
\end{tabular}

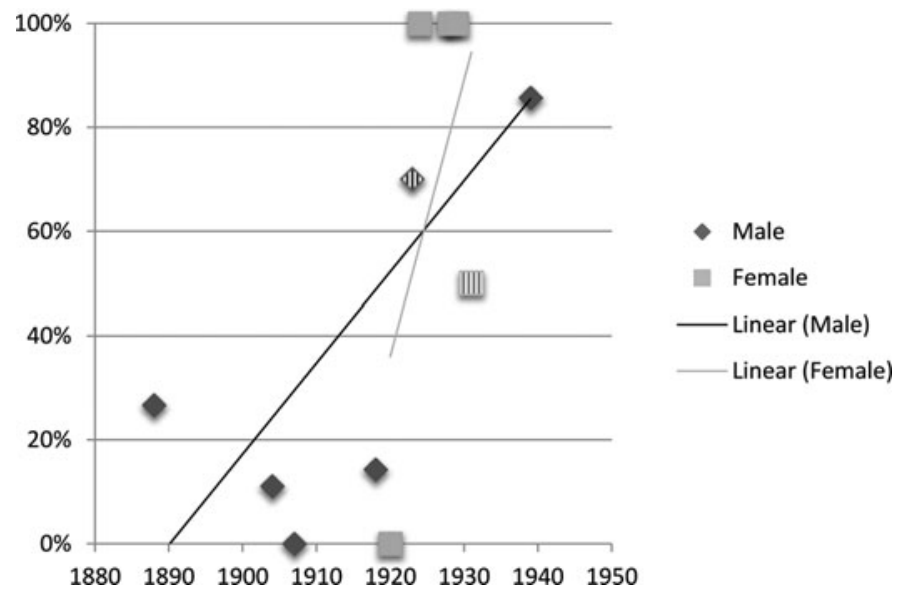

Figure 3. Rate of $/ \varepsilon /$ Lowering to [a] before / $/$ for 1977 Speakers by Birth Year. Striped symbols represent speakers born north of Golden Meadow.

$/ \mathrm{r} /$ generally increases, and this is true for both male and female speakers. A visual representation of this relationship is given in Figure 3.

The regression lines for male and female speakers in Figure 3 indicate that there is a cross-over interaction between birth year and sex. The regression lines also show that there is potentially a main effect of sex. Indeed, if the data are organized by the variable of each speaker's sex, the distribution attains statistical significance, with women lowering $/ \varepsilon /$ more often than men, $\chi^{2}$ (I, $N=77$ ) $=8.24, p=.04$. However, it is clear from Figure 3 that only one speaker born before I92I in the I977 corpus is a woman, and among the younger speakers, 
men and women pattern similarly regarding the rate of $/ \varepsilon /$ lowering. Therefore, without more female speakers born before 1920 in the sample, it is not possible to make conclusive statements about differences between male and female speakers' $/ \varepsilon /$ lowering rates in the 1977 corpus.

Regarding the variables of birthplace or place of residence, which contrast speakers of Lafourche Parish from north of Golden Meadow to those from the town of Golden Meadow or further south, chi-square tests of independence indicate that neither is able to explain differences in $/ \varepsilon /$ lowering in I977 speech. Specifically, speakers born north of Golden Meadow do not lower $/ \varepsilon /$ significantly more than speakers born south of or in Golden Meadow, $\chi^{2}(\mathrm{I}, N=77)=3.05, p=.07$. The same is true for a speaker's place of residence at the time of the interview, because speakers living north of Golden Meadow do not lower / $\varepsilon$ / significantly more often than speakers living in or south of the town, $\chi^{2}(\mathrm{I}, N=77)=\mathrm{I} .3 \mathrm{O}$, $p=.2 \mathrm{I}$. It should be noted that only three speakers were born north of Golden Meadow (JBI-I923-M, AGI-I928-M, ETI-I93I-F), and only two speakers were living north of Golden Meadow at the time of the interview (AGI-I928-M, ETII93 I-F). Just the same, the tests of significance suggest that birthplace and place of residence are not factors that can reliably explain rates of / $\varepsilon$ / lowering in 1977 Louisiana Regional French, and this is supported by the finding that year of birth is positively correlated with the rate of $/ \varepsilon /$ lowering in this time period.

Thus, in 1977 Louisiana Regional French, the rate of $/ \varepsilon /$ lowering before /r/ forms an important relationship with a speaker's age, so that speakers born before I92 I rarely or never lower $/ \varepsilon /$ before the rhotic consonant, whereas speakers born after I 92 I do so between 50\% and I00\% of the time. Statistical tests have confirmed that this pattern is not related to geography in the I977 corpus. For instance, ES2I904-M was born in Golden Meadow and was still living there at the time of the interview, but produced a single $[\mathfrak{x}]$ in place of $[\varepsilon]$ out of nine cases (a rate of I I\%), while CSI-I939-M, another informant born in Golden Meadow and still living there in 1977 , used [æ] in place of $[\varepsilon]$ in six out of seven instances (a rate of $86 \%$ ). Also, AGI-I928-M, who was born in Cut Off and living in Galliano at the time of the interview, uses [æ] exclusively (4 of 4 tokens). The next two sections will examine the data from the more formal and less formal speech registers in the 20IO-20II interviews.

\subsection{0-2011 formal speech}

When speaking to a community outsider, the 20 interviewees from the 2010-20 I I corpus produce a total of I68 tokens for analysis. As with the I977 interviewees, some speakers produce only a few tokens; however, the data available for these speakers pattern similarly to the rest of the group, and so are included in the analysis. Unlike the data from I977, the rate of / $\varepsilon$ / lowering cannot be ordered by a speaker's age, as evidenced by a non-significant rank correlation between birth year and the rate of $/ \varepsilon /$ lowering, $r_{s}=.02, \mathrm{~N}=20, p=.93$. Since all speakers in the 20IO-20I I corpus are born after I920, this result appears to conform to the 


\section{Darcie Blainey}

Table 2. / $/$ / Lowering to [a] before / $r /$ in 2010-2011 Formal Speech. $*=$ Birth year within 1977 speakers' birth year range. $C F=$ Cut Off; GL = Galliano; GM $=$ Golden Meadow.

\begin{tabular}{|c|c|c|c|c|}
\hline Speaker-Birth Year-Sex & Born In & Living In & $\mathrm{N}[\mathfrak{x}] / / \mathrm{r} /$ & $\%[æ] / / / r /$ \\
\hline RGI-I930-M* & GL & GL & O of I4 & $0.0 \%$ \\
\hline SCI-I93 I-M* & CF & GL & O of IO & $0.0 \%$ \\
\hline VTI-I933-F* & GL & GM & o of IO & $0.0 \%$ \\
\hline ACI-I937-F* & GL & GL & o of 4 & $0.0 \%$ \\
\hline LTI-I92 I-F* & GM & GM & 7 of 9 & $77.8 \%$ \\
\hline GBI-I923-F* & GM & GM & 4 of 4 & I00.0\% \\
\hline PBI-I924-F* & GM & GM & IO of I I & $90.9 \%$ \\
\hline JAI-I926-M* & GM & CF & 8 of 8 & IOO.0\% \\
\hline CGI-I928-M* & GM & GM & 8 of 9 & $88.9 \%$ \\
\hline GG2-I929-F* & GM & GL & 9 of 10 & $90.0 \%$ \\
\hline VGI-I933-M* & GM & GL & 6 of 12 & $50.0 \%$ \\
\hline ECI-I935-M* & GM & GM & 4 of 4 & I00.0\% \\
\hline JGI-I935-F* & GM & GL & 3 of 3 & I0O. $\% \%$ \\
\hline DEI-I940-F & GM & GM & 7 of 7 & IOO.O\% \\
\hline KCI-I94I-M & GM & GM & 5 of I I & $45.5 \%$ \\
\hline ALI-I945-F & GM & GM & 3 of 5 & $60.0 \%$ \\
\hline BG2-I946-F & GM & GL & 2 of 4 & $50.0 \%$ \\
\hline JRI-I947-M & GM & GM & I 8 of I 8 & I0O.0\% \\
\hline SGI-I949-M & GM & CF & 6 of 6 & I0O.०\% \\
\hline GGI-I953-M & GM & GM & 8 of 9 & $88.9 \%$ \\
\hline
\end{tabular}

generational divide seen in the 1977 data. There are, however, some speakers who never lower $/ \varepsilon /$, and this cannot be explained by their age alone. Sex is not an active variable, either, with men and women lowering / $\varepsilon /$ at roughly the same rate, $\chi^{2}(\mathrm{I}, N=\mathrm{I} 68)=.40, p=.32$. An overview of the data is presented in Table 2.

The pattern becomes more apparent if speakers are grouped by birthplace. Four of the 20 speakers were born north of Golden Meadow. Chi-square tests of independence show that speakers born in or south of Golden Meadow lower $/ \varepsilon /$ significantly more often $(N=\mathrm{IO} 8 / \mathrm{I} 4 \mathrm{O}, 77 . \mathrm{I} \%)$ than speakers born north of Golden Meadow $(N=\mathrm{o} / 28, \mathrm{o} \%), \chi^{2}(\mathrm{I}, N=\mathrm{I} 68)=60.48, p=.00$. Furthermore, even though the difference is not as great, the town in which a speaker was living at the time of the interview is also a significant variable, with speakers in or south of Golden Meadow lowering $/ \varepsilon /$ significantly more often $(N=74 / 97,76.3 \%)$ than speakers north of Golden Meadow $(N=34 / 7 \mathrm{I}, 47.9 \%), \chi^{2}(\mathrm{I}, N=\mathrm{I} 68)=\mathrm{I} 4.4 \mathrm{O}$, $p=. \mathrm{oo}$.

Figure 4 provides a visual representation of the rate of $/ \varepsilon /$ lowering by speaker in the formal speech style. In keeping with the statistical test results, the regression lines show that there is no clear relationship between a speaker's year of birth or sex and his or her rate of $/ \varepsilon /$ lowering; although there is a cross-over interaction between birth year and sex, there are no main effects present in the data. The clusters of tokens do clearly show that a speaker's birthplace effectively separates the 


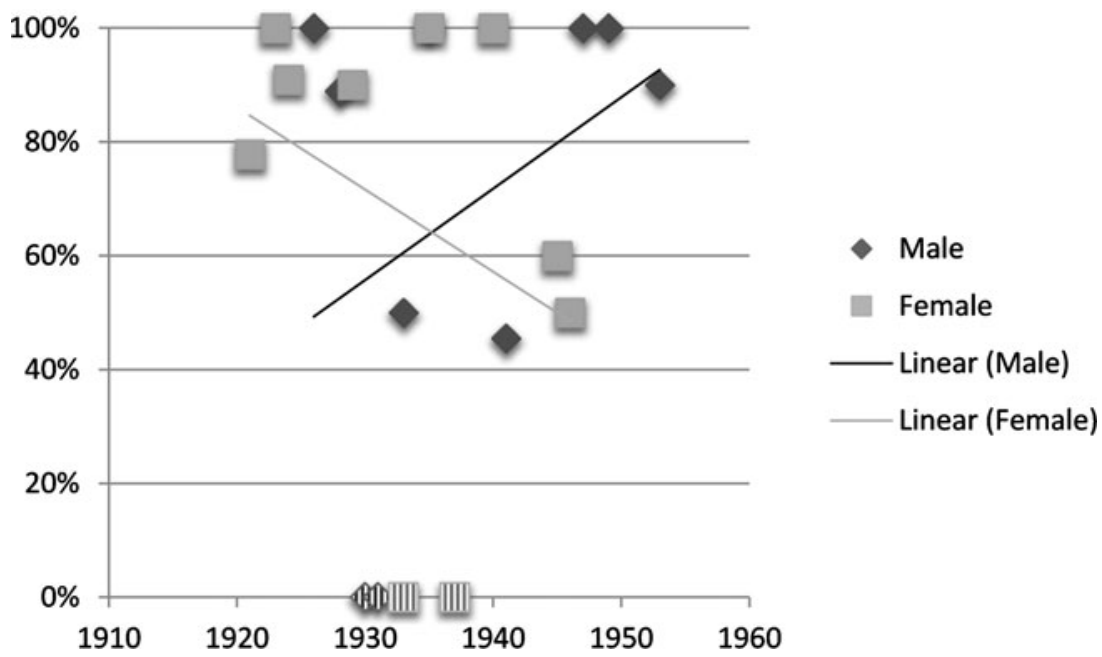

Figure 4. Rate of $/ \varepsilon /$ Lowering to [a] before / $/$ / for 2010-2011 Speakers by Birth Year, Formal Conversation. Striped symbols represent speakers born north of Golden Meadow.

data into those who lower $/ \varepsilon /$ and those who do not, since the four speakers born north of Golden Meadow are the only speakers never to lower $/ \varepsilon /$.

\subsection{0-2011 informal speech}

In the less formal 20I0-20 I speech register, speakers are conversing with a Golden Meadow native; this community insider is often also a family member or friend of the person being interviewed. Only one speaker, KCI-I94I-M, does not have any tokens available for analysis. Altogether, the informal speech register contributes I9I tokens to the analysis. Table 3 summarizes the lowering rate for each speaker, maintaining the same groupings as were made for Table 2.

Starting with non-significant variables, recall that sex was not an active variable in explaining $/ \varepsilon /$ lowering patterns in the more formal speech style. A chi-square test of independence confirms that this variable cannot help to explain variation in less formal conversation either, since men do not lower $/ \varepsilon /$ significantly more often than women, $\chi^{2}$ (I, $N=$ I9I $)=.35, p=.33$. The variable of birth year provides another set of results that are similar to those for the 20IO-20I I formal speech register. In particular, there is non-significant rank correlation between a speaker's birth year and his or her rate of $/ \varepsilon /$ lowering when speaking to a community insider, $r_{s}=. \mathrm{I} 5, \mathrm{~N}=\mathrm{I} 9, p=.54$. This suggests that birth year is not an active variable in explaining different rates of $/ \varepsilon /$ lowering in 20 Io-20 I speech.

In contrast to the more formal speech register, a person's place of residence does not have a significant effect on his or her $/ \varepsilon /$ lowering behaviour in less formal 


\section{Darcie Blainey}

Table 3. / / / Lowering to [a] before / $r /$ for 2010-2011 Informal Speech. $\downarrow=$ significant decrease in $/ \varepsilon /$ lowering compared to the 2010-F Speech data. $*=$ Birth year within 1977 speakers' birth year range. $C F=$ Cut Off; GL $=$ Galliano; $G M$ $=$ Golden Meadow.

\begin{tabular}{|c|c|c|c|c|}
\hline Speaker-Birth Year-Sex & Born In & Living In & $\mathrm{N}[\mathfrak{x}] / / \mathrm{r} /$ & 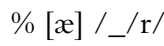 \\
\hline RGI-I930-M* & GL & GL & O of IO & $0.0 \%$ \\
\hline SCI-I93 I-M* & CF & GL & o of Io & $0.0 \%$ \\
\hline VTI-I933-F* & GL & GM & o of 15 & $0.0 \%$ \\
\hline ACI-I937-F* & GL & GL & o of 5 & $0.0 \%$ \\
\hline LTI-I92 I-F* & GM & GM & 5 of 10 & $50.0 \%$ \\
\hline GBI-I923-F* & GM & GM & 6 of 6 & I $00.0 \%$ \\
\hline PBI-I924-F* & GM & GM & 4 of 8 & $50.0 \%$ \\
\hline JAI-I926-M* & GM & CF & 5 of 5 & IOO.०\% \\
\hline CGI-I928-M* & GM & GM & 3 of 7 & $42.9 \%$ \\
\hline GG2-I929-F* & GM & GL & 4 of 7 & $57.1 \%$ \\
\hline VGI-I933-M* & GM & GL & IO of I4 & $71.4 \%$ \\
\hline ECI-I935-M* & GM & GM & I I of I 5 & $73 \cdot 3 \%$ \\
\hline JGI-I935-F* & GM & GL & 8 of 8 & IOO.०\% \\
\hline DEI-I940-F & GM & GM & IO of I4 & $7 \mathrm{I} .4 \%$ \\
\hline KCI-I94I-M & GM & GM & $\mathrm{N} / \mathrm{A}$ & $\mathrm{N} / \mathrm{A}$ \\
\hline ALI-I945-F & GM & GM & 6 of I I & $54.5 \%$ \\
\hline BG2-I946-F & GM & GL & 5 of 7 & $71.4 \%$ \\
\hline JRI-I947-M & GM & GM & 5 of 8 & $62.5 \% \downarrow$ \\
\hline SGI-I949-M & GM & CF & 5 of 5 & I00.0\% \\
\hline GGI-I953-M & GM & GM & I 8 of 26 & $69.2 \%$ \\
\hline
\end{tabular}

conversation, with people living in or south of Golden Meadow only lowering $/ \varepsilon$ / slightly more often than those living north of the town, $\chi^{2}(\mathrm{I}, N=\mathrm{I}$ I $)=.37$, $p=.32$.

The only significant factor in 20 I0-20 I i informal speech is a speaker's birthplace. Specifically, speakers born in or south of Golden Meadow lower / $/$ / $65.2 \%$ of the time $(N=$ I05/I6I), while speakers born north of Golden Meadow never lower $/ \varepsilon$ / $(N=0 / 30)$. A chi-square test of independence shows this to be highly significant, $\chi^{2}(\mathrm{I}, N=\mathrm{I}, \mathrm{I})=43.45, p=.00$. This pattern is clearly visible in Figure 5 . The regression lines in Figure 5 show the same cross-over interaction between sex and age that has been seen in the other data sets, but again, there are no main effects.

\subsection{Comparison of data sets}

A chi-square test of independence shows that the I977 data set does not differ significantly from the 20IO-20 I formal speech style, $\chi^{2}(\mathrm{I}, N=245)=2.70, p=$ .07. The I977 data are even more similar to the 20I0-20 I i informal speech style, with lowered $/ \varepsilon /$ appearing $53.2 \%$ of the time $(N=4 \mathrm{I} / 77)$ in 1977 and $55.0 \%$ of the time $(N=$ IO5/I9I) in 20IO-20I I informal conversation; there is no statistical difference between the two data sets, $\chi^{2}(\mathrm{I}, N=268)=.07, p=.45$. However, 


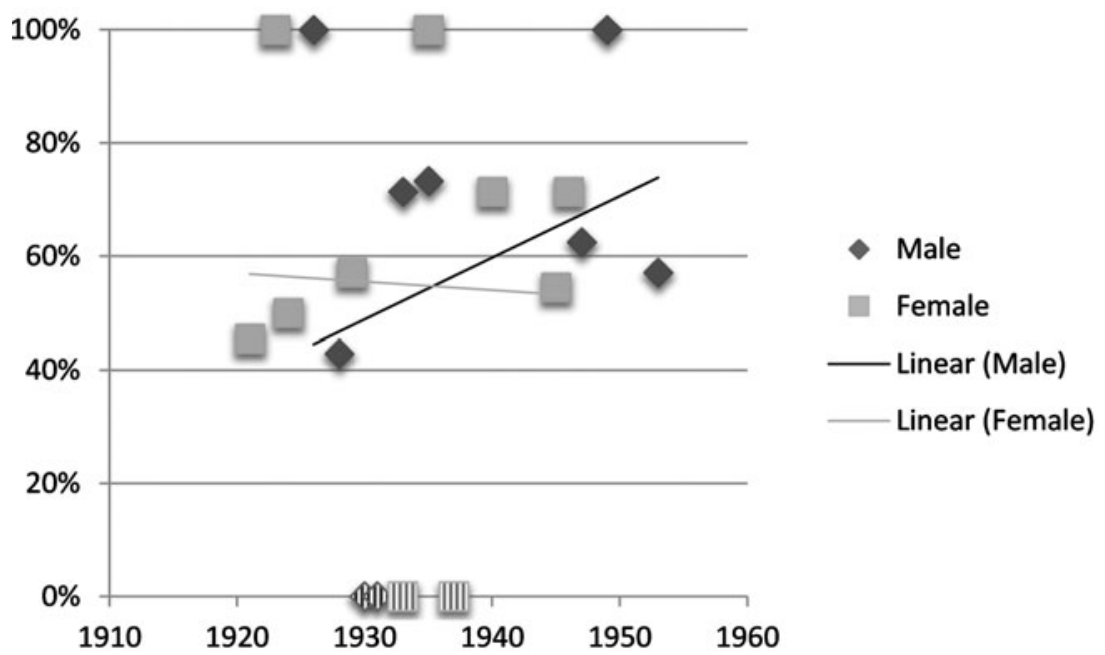

Figure 5. Rate of $/ \varepsilon /$ Lowering to [a] before $/ r /$ for 2010-2011 Speakers by Birth Year, Informal Conversation. Striped symbols represent speakers born north of Golden Meadow.

there is a statistically significant difference between the two speech registers of the 20IO-20I I interviews, with speakers lowering $/ \varepsilon /$ significantly more often in careful speech $(N=\mathrm{I08} / \mathrm{I} 68,64.3 \%)$ than in less careful speech $(N=\mathrm{I05} / \mathrm{I} 9 \mathrm{I}$, $55.0 \%), \chi^{2}(\mathrm{I}, N=359)=3.2 \mathrm{I}, p>.05$. Interestingly, after performing a two-tailed Fischer's exact test for each speaker in the 20IO-20I I corpus, only one speaker, JRI-I947-M, had statistically significant differences in $/ \varepsilon /$ lowering between the two speech styles $(\chi, \mathrm{df}=\mathrm{I} ; p=.02)$. Thus, while the group as a whole lowers $/ \varepsilon /$ less often when speaking to a community insider, suggesting a style-based contrast, this is generally not statistically significant at the individual level.

\section{DISCUSSION}

\subsection{7 trends}

In the I977 recordings, speakers born before I92 I lower $/ \varepsilon /$ to [æ] before $/ \mathrm{r} /$ between $0 \%$ and $27 \%$ of the time; speakers born during or after I92 I lower $/ \varepsilon$ / between $50 \%$ and $100 \%$ of the time. A potential explanation for the significant generational divide arises when we consider the history of Golden Meadow, and the natural disasters that led to the formation of its core population.

As mentioned in the $/ \varepsilon /$ lowering in North American French section, lowering / $\varepsilon$ /

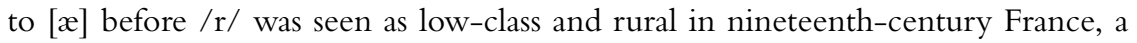
time at which many speakers left France for Louisiana. The cosmopolitan fishing settlement of Chenière Caminada, located on the barrier islands at the base of bayou Lafourche, included many French families. These people suffered through two 


\section{Darcie Blainey}

major natural disasters. First, in I 893, a devastating hurricane obliterated Chenière Caminada. Any surviving residents resettled further north on the bayou in the towns of Leeville and Golden Meadow (Falls, I893). Second, in I9I5, another hurricane virtually destroyed Leeville (Roth, 2010: 30), forcing survivors to move north again to Golden Meadow. This substantial population increase allowed for the establishment of many new Golden Meadow businesses and institutions in the I920s, such as a Catholic church, shrimp and ice factories, as well as a grocery store, bank, and movie theatre (Rome, I996: 72). The I930s saw even more development with the discovery of oil wells in the parish; electricity, the petroleum industry and education were not long in following.

The hurricanes represented major ruptures in everyday life for people living south of Golden Meadow, and the business developments in the I920s and I930s firmly established Golden Meadow as a community on bayou Lafourche. People born in the I920s in lower Lafourche Parish thus experienced a much different everyday reality growing up than the generation before. It is possible that this younger generation sought to distinguish itself from older speakers by using a salient phonetic feature such as $/ \varepsilon /$ lowering at a much higher rate. These events and social changes help to explain why there exists a generational divide in $/ \varepsilon$ / lowering patterns among those speakers interviewed in 1977.

\subsection{7 to 2010-2011 trends}

This study includes a subset of speakers born during the same time period (I92 II939) but interviewed nearly forty years apart (in I977 and in 20IO-20 I I). Isolating the $/ \varepsilon /$ lowering rates for these speakers allows a comparison of the data sets based solely on the point in time at which a speaker was interviewed. There are seven speakers from I977 who fall into this age range (three men and four women), while I 3 speakers from 20I0-20 I I (six male and seven female) are born in the same period of time. Figure 6 combines the $/ \varepsilon /$ lowering rates for a subset of speakers interviewed in I977 and in 20IO-20 I in the less formal speech setting, since these two data sets are not significantly different from one another, and highlights speakers born north of Golden Meadow by representing them with striped symbols.

Figure 6 shows that for speakers within this age range who were interviewed in 1977 , the same pattern of $/ \varepsilon /$ lowering applies regardless of birthplace. For instance, AGI-I928-M was born and living north of Golden Meadow when he was interviewed, but always lowers / $\varepsilon /$; ET I-I93 I-F was also born and living north of the town when she was recorded, but lowers $/ \varepsilon / 50 \%$ of the time. In I977, then, residents of the towns of Galliano and Cut Off did not use this pronunciation pattern to distinguish themselves from the residents of Golden Meadow.

It is clear that this pattern is different in 20IO-20 I f for speakers born during the same time period in the same tight geographical area. Speakers interviewed in 20 IO20 I I employ the process of $/ \varepsilon /$ lowering to make a strong divide between Golden Meadow and two otherwise comparable settlements in south Lafourche Parish. In 20іо-20і I, / $/$ / lowering has therefore come to characterize the speech of people 


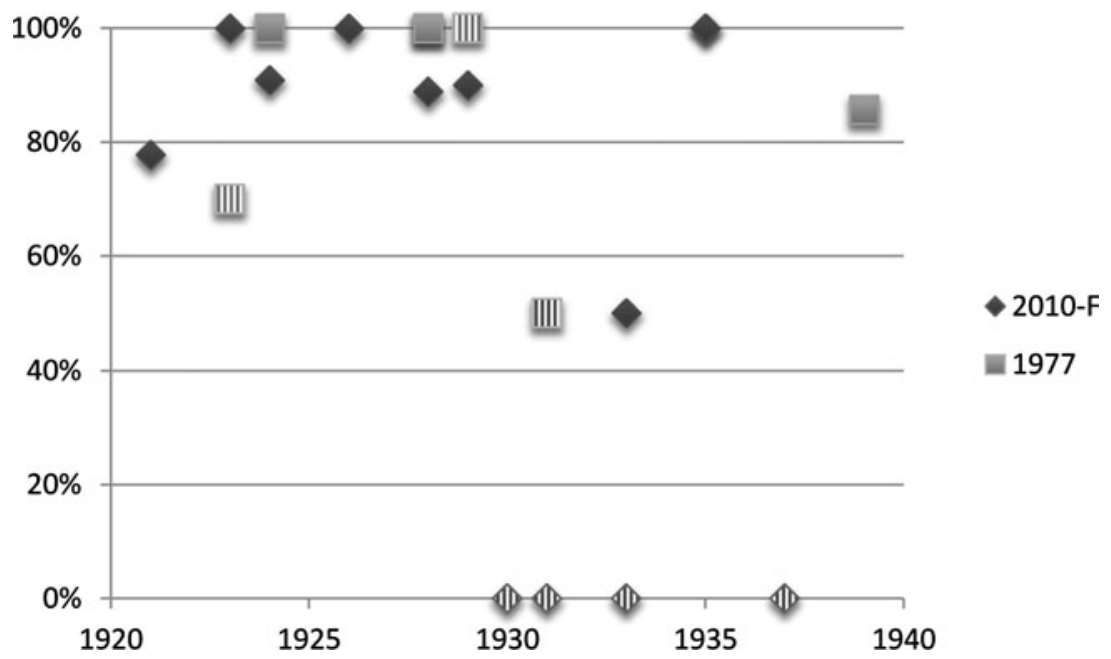

Figure 6. Rate of $/ \varepsilon /$ Lowering to $[a]$ before $/ r /$ for 1977 and 2010-2011 Speakers (Informal Conversation) by Birth Year (1921-1939). Striped symbols represent speakers born north of Golden Meadow.

born in or south of Golden Meadow, and is no longer present among people born in Cut Off or Galliano. While not all speakers are necessarily conscious of this isogloss boundary, the community insider performing the 2010-20 I informal interviews delighted in eliciting this shibboleth from Galliano and Cut Off natives in order to show how their French differed from that of Golden Meadow. There is, therefore, at least some awareness within the lower Lafourche Parish Francophone communities that this pronunciation divide exists, and that it represents a strong town-based identity for residents of Golden Meadow.

\subsection{Comparison with previous research}

It is possible to compare the 20IO-20I I data from the present study to a subset of Salmon's (2007: I87-I90) / $\varepsilon /$ lowering data. In particular, six of Salmon's female speakers come from Lafourche Parish. These women were born in Galliano, Cut Off, and Raceland between I9Io and I938. It is not possible to consider the effect of time period in the comparison, because all of Salmon's Lafourche speakers were interviewed in I997. However, her speech sample represents an intermediate point between the I977 and 20I0-20I I recordings in the present study.

The results in Salmon (2007: I 87-I90) indicate that Lafourche Parish Louisiana Regional French speakers lower $/ \varepsilon /$ between $0 \%$ and $31.7 \%$ of the time in more careful speech with a community outsider, and between $0 \%$ and $8.6 \%$ of the time when speaking to a native Louisiana Regional French speaker. Naturally, these rates of $/ \varepsilon /$ lowering are much lower than those seen in the present study, because in 


\section{Darcie Blainey}

20IO-2OI I, / $\varepsilon$ / lowering has been shown to be an active identity marker for people born in or south of Golden Meadow, and all interviewees in Salmon (2007, 2009) were born north of Golden Meadow. Also, Salmon (2007, 2009) notes the same statistically significant decrease in $/ \varepsilon /$ l lowering when comparing careful and less careful speech, which is in accordance with the current study's findings.

Dubois (2005: 298) reports that Lafourche Parish speakers lower / $\varepsilon / 26 \%$ of the time. Although it is not possible to directly compare the current study's findings with those of Dubois (2005), it is reasonable to expect that the differences in $/ \varepsilon /$ lowering rates between the two investigations stem from the same demographic difference, since Salmon's $(2007,2009)$ speakers come from the same corpus used in the larger Dubois (2005) study. The current study's findings are thus not incompatible with these previous investigations.

Dubois (2005) and Salmon (2007, 2009) divide their speakers by generation, basing birth year ranges on language learning experiences. One such generational division separates the 'elders' (doyens), born between I905 and I9I5, from the 'old generation' (aînés), born between I9I9 and I933 (Dubois, Noetzel and Salmon, 2005: 29). The current study has shown that in I977 Louisiana Regional French, speakers born before I92 I rarely or never lower $/ \varepsilon /$ before $/ \mathrm{r} /$, while speakers born after I92 I do so between 50 and 100\% of the time. This trend appears to correspond to the doyen - aîné generational divide in Dubois (2005) and Salmon (2007, 2009). In the current investigation, there are no other generation-based differences in $/ \varepsilon /$ lowering. Speakers born after 1933, termed the 'middle-aged generation' (cadets, I934-I95I) and 'young generation' (benjamins, I953-I978) in previous studies (Dubois and Noetzel, 2005: I33; Dubois, 2005: 288-290), do not lower $/ \varepsilon /$ any more or less than speakers born before I933.

Guilbeau's (1958) lower Lafourche Parish informants were interviewed in the I940s, and would therefore be expected to lower / $/ \varepsilon /$ between 50\% and I00\% of the time according to the present analysis. While Guilbeau (I958) does not give quantitative measures of $/ \varepsilon /$ lowering in his article, he does remark that this process happens most of the time for speakers in the lower half of the parish. This matches the current study's findings exactly. Therefore, some previous sociolinguistic research regarding / $\varepsilon$ / lowering in Lafourche Parish French presents different findings from the present study because of demographic differences in the population samples. Otherwise, earlier descriptions of this process in lower Lafourche Parish are compatible with the patterns found in the current analysis.

\section{CONCLUSION}

This sociolinguistic study has used I 2 recordings from 1977 and 20 recordings from 2OIO-2OII in order to explore the process of $/ \varepsilon /$ lowering before $/ \mathrm{r} /$ in lower Lafourche Parish. By taking birthplace and place of residence into account, this analysis has succeeded in showing a previously undocumented isogloss boundary between Golden Meadow and Galliano. The historical aspect of the examination 
has revealed the social roots of the $/ \varepsilon /$ lowering process, as well as a change in the factors controlling $/ \varepsilon /$ lowering rates over the past 40 years.

With reference to previous studies, this paper laid out three new hypotheses regarding $/ \varepsilon /$ lowering in lower Lafourche Parish. The first, that $/ \varepsilon /$ would lower to [æ] more frequently for speakers interviewed in the I94Os than for speakers interviewed in the I970s and 2000s, was not able to be tested by the present analysis and awaits future examination. The second hypothesis, that the point in time at which speakers were interviewed would play a role in the process of $/ \varepsilon /$ lowering before $/ \mathrm{r} /$, proved to be correct: the factors determining the rate of $/ \varepsilon /$ lowering changed between the I 977 and 20 I0-20 I r recordings. The third hypothesis was that sociolinguistic factors would play an active role in the rate of $/ \varepsilon /$ lowering. This hypothesis was also correct, but different sociolinguistic factors were statistically significant for different subsets of the data.

Thus, what was a generational marker in 1977 has become a geographical marker in 2OIO-2OII, demonstrating that $/ \varepsilon /$ lowering to [æ] before $/ \mathrm{r} /$ has changed in meaning over time. Results from the 20IO-20 I data also suggest that the formality of the speech event has a significant effect on the rate of $/ \varepsilon /$ lowering, with speakers generally using the lowered variant [æ] less often in less careful speech, despite the severely endangered status of Louisiana Regional French. This may be due to the fact that in the informal speech register, performance of town affiliation identity is not as crucial, because speakers are confident that the interviewer is already aware of their community membership. Finally, the current study's results refine earlier statements regarding / $\varepsilon$ / lowering in Lafourche Parish Louisiana Regional French, showing that in the southern half of the parish, this variable represents an isogloss boundary between Golden Meadow and Galliano.

Louisiana Regional French speakers, like speakers of Jèrriais, 'are less likely to be influenced by any prescriptive norms or intuitive tendencies associated with the standard than speakers of the dialects of mainland France' (Jones, 20I2: 20I). The exploration and analysis of seriously endangered varieties of French, especially those varieties whose speakers have little contact with a written code, allows for interesting insights into sound pattern changes, innovation and variability over time.

Address for correspondence:

Department of Linguistics

University of Toronto

Sidney Smith Hall, 4th floor

100 St. George St.

Toronto, Ontario

Canada $\mathrm{M}_{5} \mathrm{~S}_{3} \mathrm{G}_{3}$

e-mail:darcie.blainey@utoronto.ca

REFERENCES

Baronian, L. (2005). Pre-Acadian Cajun French. Papers from the 31st Annual Meeting of the Berkeley Linguistics Society. Berkeley: Berkeley Linguistics Society, pp. 37-48. 


\section{Darcie Blainey}

Blainey, D. (20I3). First to come, last to go: Phonological change and resilience in Louisiana Regional French. Doctoral dissertation, Tulane University.

Brasseaux, C. (1985). Acadian Life in the Lafourche Country, I766-I803. In: P. D. Uzee (ed), The Lafourche Country: The People and the Land. Lafayette: Center for Louisiana Studies, University of Southwestern Louisiana, pp. 33-42.

Brasseaux, C. (1992). Acadian to Cajun: Transformation of a People, 1803-1877. Jackson: University Press of Mississippi.

Brasseaux, C. (2005). French, Cajun, Creole, Houma: a Primer on Francophone Lonisiana. Baton Rouge: Louisiana State University Press.

Brenzinger, M., Dwyer, A., de Graaf, T., Grinevald, C., Krauss, M., Miyaoka, O., Ostler, N., Sakiyama, O., Villalón, M., Yamamoto, A. and Zapeda, O. (2003). Language vitality and endangerment. International Expert Meeting on UNESCO Programme Safeguarding of Endangered Languages. Paris, pp. I-25.

Breton, R. and Louder, D. (I979). La géographie linguistique de l'Acadiana. Cahiers de géographie du Québec, 23.59: 217-238.

Brown, B. (2005). L'élaboration d'une norme endogène en Louisiane francophone. In: A. Valdman, J. Auger and D. Piston-Hatlen (eds), Le français en Amérique du Nord: état présent. Sainte-Foy: Les Presses de l’Université Laval, pp. 389-409.

Byers, B. (1988). Defining norms for a non-standardized language: A study of verb and pronoun variation in Cajun French. Doctoral dissertation, Indiana University.

Carmichael, K. (2007). Gender differences in the substitution of $/ \mathrm{h} / \mathrm{for} / 3 /$ in a formal register of an endangered dialect of Louisiana French. Southern Journal of Linguistics, 3I.2: I-27.

Carmichael, K. (2008). Language death and stylistic variation: An intergenerational study of the substitution of $/ \mathrm{h} /$ for $/ 3 /$ in the French of the Pointe-Au-Chien Indians. Master's thesis, Tulane University.

Census Bureau, United States (2000). Louisiana - Parishes. Census 2000.

Center for Cultural \& Eco-Tourism (CCeT) (2007). Lafayette: Louisiana Digital Folklore Archive. http://ccet.louisiana.edu/tourism/cultural/archives.html.

Conwell, M. and Juilland, A. (1963). Louisiana French Grammar. The Hague: Mouton.

Dajko, N. (2009). Ethnic and geographic variation in the French of the Lafourche Basin. Doctoral dissertation, Tulane University.

Dajko, N., Crossland, M., Fort, A., French, A., Goss, W., Johnson, C., Hinrichs, C., Powers, R., Pulwer, R., Schneider, A., Shipps, G., Snider, S. and Williams, D. (2008). 'Every town has a different way of talking': Variation in the French spoken in Lafourche Parish. Symposium on Louisiana Dialects and Cultures. Baton Rouge, Louisiana.

Dubois, S. (2005). Un siècle de français cadien parlé en Louisiane: persistance linguistique, hétérogénéité géographique et évolution. In: A. Valdman, J. Auger and D. Piston-Hatlen (eds), Le français en Amérique du Nord: état présent. Sainte-Foy: Les Presses de l'Université Laval, pp. 287-305.

Dubois, S., Leumas, E. and Richardson, M. (2007). Spatial diffusion of language practices within the Catholic church in Louisiana. University of Pennsylvania Working Papers in Linguistics, I 3.2: 5I-63.

Dubois, S. and Noetzel, S. (2005). Intergenerational pattern of interference and internally-motivated changes in Cajun French. Bilingualism: Language and Cognition, 8.2: $\mathrm{I} 3 \mathrm{I}-\mathrm{I} 43$. 
Dubois, S., Noetzel, S. and Salmon, C. (2005). Les innovations en français cadien: interférences ou changements motivés de façon interne au système? In: P. Brasseur and A. Falkert (eds), Français d'Amérique: Approches Morphosyntaxiques. Actes du colloque international Grammaire comparée des variétés de français d'Amérique (Université d'Avignon, 17-20 mai 2004). Paris: L'Harmattan, pp. 27-38.

Durand, J., Laks, B. and Lyche, C. (2002). La phonologie du français contemporain: usages, variétés et structures. In: C. D. Pusch and W. Raible (eds), Romanistische Korpuslinguistik- Korpora und gesprochene Sprache. Tübingen: Gunter Narr Verlag, pp. 93-106.

Durand, J., Laks, B. and Lyche, C. (2005). Un corpus numérisé pour la phonologie du français. In: G. Williams (ed), La linguistique de corpus. Rennes: Presses universitaires de Rennes.

Falkert, A. (20I0). Le français acadien des Îles-de-la-Madeleine: étude de la variation phonétique. Paris: L'Harmattan.

Falls, R. (I893). Chenière Caminada, or, The wind of death. The story of the storm in Louisiana. New Orleans: Hopkins' Printing Office.

Flikeid, K. (1984). La variation phonétique dans le parler acadien du nord-est du NouveauBrunswick: étude sociolinguistique. New York: Peter Lang.

Fortier, A. (I89I). The Acadians of Louisiana and their dialect. Publications of the Modern Language Association of America, 6. I: 64-94.

Guilbeau, J. (I950). The French spoken in Lafourche Parish, Louisiana. Doctoral dissertation, University of North Carolina Chapel Hill.

Guilbeau, J. (1958). La phonologie et les études des parlers franco-louisianais. Comptesrendus de l'Athenée louisianais: 28-39.

Hull, A. (I956). The Franco-Canadian dialect of Windsor, Ontario: a preliminary study. Orbis, 5: 35-60.

Hurst, H. (1936). A glossary of the French spoken in St. Charles Parish. Master's Thesis, Louisiana State University.

Jones, M. (200I). Jersey Norman French: A Linguistic Study of an Obsolescent Dialect. Oxford: Blackwell.

Jones, M. (2005). Some structural and social correlates of single word intrasentential code-switching in Jersey Norman French. Journal of French Language Studies, I 5: I23.

Jones, M. (2012). Liaison patterns and usage in Jersey Norman French. Probus, 24.2: I97-232.

Klingler, T. and Lafleur, A. (2007). L'enquête PFC en Louisiane. In: S. Detey and D. Nouveau (eds), Bulletin PFC N. 7 : PFC: enjeux descriptifs, théoriques et didactiques 2007. Toulouse: Université de Toulouse II, pp. 33 I-340.

Labov, W. (1984). Field methods of the Project in Linguistic Change and Variation. In: J. Baugh and J. Sherzer (eds), Language in Use: Readings in Sociolinguistics. Englewood Cliffs: Prentice-Hall, pp. 28-53.

Lafourche Parish Government (20I2). ParishBlackWhite.jpg. Image retrieved December I 5, 20I2, http://www.lafourchegov.org/parishimages/ParishBlackWhite.jpg.

Larouche, A. (I979). Les cadjins du Canal Yankee: Problèmes d'identité culturelle dans la paroisse Lafourche. Cahiers de Géographie du Québec, 23.59: 239-262.

Larouche, A. (1980). Ethnicité, pêche et pétrole: Les cadjins du Bayou Lafourche en Louisiane francophone. Master's thesis, York University. 


\section{Darcie Blainey}

Leumas, E. (2009). Mais, I sin in French, I gotta go to confession in French: A Study of the Language Shift from French to English within the Louisiana Catholic Church. Doctoral Dissertation, Louisiana State University.

Lodge, R. A. (2004). A Sociolinguistic History of Parisian French. Cambridge: Cambridge University Press.

Louder, D. and Waddell, E. (I979). À la recherche de la Louisiane française. Cahiers de Géographie du Québec, 23.59: I93-I97.

Montgomery, E. (I94I). A glossary of variants from Standard French in Vermilion Parish. Master's Thesis, Louisiana State University.

Neumann, I. (1985). Le créole de Breaux Bridge, Louisiane: étude morphosyntaxique, textes, vocabulaire. Hamburg: Helmut Buske Verlag.

Picone, M. (1998). Historic French diglossia in Louisiana. 58th Annual Meeting of the Southeastern Conference on Linguistics (SECOL). University of Southwestern Louisiana, Lafayette.

Picone, M. and Valdman, A. (2005). La situation du français en Louisiane. In: A. Valdman, J. Auger and D. Piston-Hatlen (eds), Le français en Amérique du Nord : état présent. Sainte-Foy: Les Presses de l'Université Laval, pp. I43-I65.

Pitre, Jr., L. (I996). A late nineteenth-century coastal Cajun Community: Cheniere Caminada avant l'Ouragan. In: S. S. Michot and J. P. Doucet (eds), The Lafourche Country II: The Heritage and Its Keepers. Thibodaux: Lafourche Heritage Society, pp. SI-70.

Read, W. (I93 I). Louisiana-French. Baton Rouge: Louisiana State University Press.

Read, W. (1938). Some Louisiana-French words. Zeitschrift für französische Sprache und Literatur, 6I.I/2: 62-84.

Rome, J. (1996). A history of Golden Meadow. In: S. S. Michot and J. P. Doucet (eds), The Lafourche Country II: The Heritage and Its Keepers. Thibodaux: Lafourche Heritage Society, pp. 7I-74.

Roth, D. (2010). Louisiana hurricane history. Camp Springs: National Weather Service.

Rottet, K. (I995). Language shift and language death in the Cajun French-speaking communities of Terrebonne and Lafourche Parishes, Louisiana. Doctoral dissertation, Indiana University.

Rottet, K. (2004). Inanimate interrogatives and settlement patterns in Francophone Louisiana. Journal of French Language Studies, I4.2: I69-I88.

Salmon, C. (2007). Français acadien, français cadien: variation stylistique et maintenance de formes phonétiques dans le parler de quatre générations de femmes cadiennes. Doctoral dissertation, Louisiana State University.

Salmon, C. (2009). Cent ans de français cadien en Louisiane : étude sociolinguistique du parler des femmes. New York: Peter Lang.

Salmon, C. (2013). Personal communication, January I9.

Smith, T. (1934). An analysis of rural social organization among the French-Speaking people of Southern Louisiana. American Journal of Agricultural Economics, I6.4: 680-688.

Thogmartin, C. (1974). The phonology of three varieties of French in Manitoba. Orbis, 23.2: $335-345$.

Trappey, M. (I940). The French speech of Iberia Parish. Master's Thesis, Louisiana State University.

Trépanier, C. (I99I). The cajunization of French Louisiana: Forging a regional identity. Geographical Journal, I 57.2: I6I-I7I.

Walker, D. (I984). The Pronunciation of Canadian French. Ottawa: University of Ottawa Press. 